\title{
Functionalized Plasmonic Nanostructure Arrays for Direct and Accurate Mapping Extracellular pH of Living Cells in Complex Media Using SERS
}

Fang Sun, Peng Zhang, Tao Bai, Daniel David Galvan, Hsiang-Chieh Hung, Nan Zhou, Shaoyi Jiang, and Qiuming $Y u$ *

F. Sun, P. Zhang, T. Bai, D.D. Galvan, Dr. H. Hung, N. Zhou, Prof. S. Jiang and Prof. Q. Yu Department of Chemical Engineering, University of Washington, Seattle WA 98195, USA E-mail: qyu@u.washington.edu

Abstract: The extracellular $\mathrm{pH}\left(\mathrm{pH}_{\mathrm{e}}\right)$ of living cells is one of the major factors that influence cell behaviors including cycle progression, migration, and proliferation, as well as metastasis and invasion of tumor cells. Thus, accurate sensing and mapping of the $\mathrm{pH}_{\mathrm{e}}$ is still a critical yet challenging task in the study of $\mathrm{pH}_{\mathrm{e}}$-dependent cell behaviors. In this work, we present a method to map $\mathrm{pH}_{\mathrm{e}}$ of living cells based on surface-enhanced Raman spectroscopy (SERS). We immobilized a pH probe molecule, 4-mercaptobenzoic acid (4-MBA), on a gold quasi three-dimensional plasmonic nanostructure array (Q3D-PNA) to enable an exceptionally sensitive and reproducible $\mathrm{pH}$ measurement. We prudentially investigated the influences of cations and complexity of detecting solutions on the responses of 4-MBA SERS spectra to $\mathrm{pH}$ variations to ensure the accuracy. Herein, a normal cell line (NIH/3T3) and a tumor cell line (HepG2) were cultured on the 4-MBA modified SERS substrates. Localized $\mathrm{pH}_{\mathrm{e}}$ was detected and mapped with good spatial resolution and $\mathrm{pH}$ sensitivity showing $\mathrm{pH}_{\mathrm{e}}$ domains on both cells. Moreover, the averaged $\mathrm{pH}_{\mathrm{e}}$ of tumor cells was shown to be more acidic compared with that of normal cells.

Keywords: extracellular $\mathrm{pH} \bullet$ mapping $\bullet$ tumor cell • surface-enhanced Raman scattering 


\section{Introduction}

The extracellular $\mathrm{pH}\left(\mathrm{pH}_{\mathrm{e}}\right)$ plays a critical role in the function and metabolism of cells. The molecular processes involved in cell cycle progression, proliferation, and differentiation are all influenced by the extracellular acidity (Song et al. 2006). In addition, the $\mathrm{pH}_{\mathrm{e}}$ of tumor cells is suggested to be more acidic than the normal cells. Tumor cells can secrete protons $\left(\mathrm{H}^{+}\right)$ through ion exchangers on the plasma membrane acidifying their extracellular environment, which is related with the tumor cells' adhesion, malignant transformation, and metastasis (Webb et al. 2011). Meanwhile, the $\mathrm{pH}$ gradient across the membrane affects the response of tumors to various treatments such as chemotherapy, radiotherapy and hyperthermia. The effects of $\mathrm{pH}_{\mathrm{e}}$ on immune functions have also been reported (Lardner 2001). Thus, an accurate method to measure the extracellular $\mathrm{pH}$ is highly desirable. More challenges are posted in mapping the $\mathrm{pH}_{\mathrm{e}}$ distributions of single living cells with good spatial resolution and $\mathrm{pH}$ sensitivity.

Glass or fiber optic $\mathrm{pH}$ microelectrodes were used to determine the $\mathrm{pH}_{\mathrm{e}}$ of animal and human tumors (Gerweck and Seetharaman 1996). However, these invasive techniques are not suitable for the mapping of $\mathrm{pH}_{\mathrm{e}}$ on a single living cell because the diameters of the electrodes are larger than those of cells. Tumor $\mathrm{pH}_{\mathrm{e}}$ can be mapped noninvasively by magnetic resonance spectroscopic imaging (García-Martín et al. 2001; Gillies et al. 2002). However, the mapping is usually conducted on a larger region of tumor tissue, and the spatial resolution is too low to be applied for the study of single living cells. Fluorescence-based $\mathrm{pH}$ probes provide excellent spatial resolution, but most have been designed to detect the intracellular $\mathrm{pH}$ (Bizzarri et al. 2006). Recently, several fluorescent $\mathrm{pH}_{\mathrm{e}}$ indicators were developed based on the linked membrane protein or lipid-DNA for cell-surface anchoring (Ke et al. 2014). However, whether the probe can be anchored uniformly on the membrane without forming domains is 
questionable and the process is complex. Furthermore, the fluorophores are prone to bleaching under repeated and intense illuminations.

Raman microspectroscopy is a rapid, noninvasive, and label-free technique that can be used to analyze and image cells with local molecular specificity. Surface-enhanced Raman spectroscopy (SERS) can magnify the Raman signals of molecules or species in the proximity of the surfaces of plasmonic nanostructures a million fold, rendering ultra-sensitivity (Schlucker 2014). pH sensing based on SERS has been explored before (Bishnoi et al. 2006; Kneipp et al. 2007; Pallaoro et al. 2010; Scaffidi et al. 2009; Talley et al. 2004). Several groups have demonstrated that the $\mathrm{pH}$ of solutions and living cells can be detected by using gold or silver nanoparticles functionalized with 4-mercaptobenzoic acid (4-MBA), a probe molecule with a $\mathrm{pH}$ dependent SERS spectrum. Since the functionalized nanoparticles were taken up by the cells, intracellular $\mathrm{pH}\left(\mathrm{pH}_{\mathrm{i}}\right)$ rather than $\mathrm{pH}_{\mathrm{e}}$ were measured. In addition, due to the clustering of nanoparticles and uncontrolled uptake process, it is difficult to obtain reproducible and accurate $\mathrm{pH}$ measurement and mapping. In contrast, using a two-dimensional SERS-active surface instead of nanoparticles can prevent cell uptake, enabling the measurement and mapping of $\mathrm{pH}_{\mathrm{e}}$ of cells.

Herein, we immobilized 4-MBA on a gold quasi three-dimensional plasmonic nanostructure array (Q3D-PNA) to map the local $\mathrm{pH}_{\mathrm{e}}$ of single living cells using SERS (Figure 1). The 4-MBA functionalized Q3D-PNA SERS substrates demonstrated good sensitivity and reproducibility across the entire nanopatterned area for the $\mathrm{pH}$ measurement, which are essential for SERS $\mathrm{pH}_{\mathrm{e}}$ mapping of single living cells. The influence of cations in detecting solutions on the responses of 4-MBA SERS spectra to $\mathrm{pH}$ variations were investigated and the calibration curves were established to ensure the detection and mapping accuracy in complex media such as cell culture media. As a proof of concept, a normal cell line $(\mathrm{NIH} / 3 \mathrm{~T} 3)$ and a tumor cell line (HepG2) were cultured on the 4-MBA modified Q3D- 
PNA SERS substrates. The values of local $\mathrm{pH}_{\mathrm{e}}$ of living cells were detected and mapped with high spatial resolution and $\mathrm{pH}$ sensitivity. The tumor cells displayed more acidic averaged $\mathrm{pH}_{\mathrm{e}}$.

\section{Experimental section}

\subsection{Materials}

4-Mercaptobenzoic acid (4-MBA, 99\%), phosphate buffered saline packet (PBS, pH 7.4 and ionic strength $150 \mathrm{mM})$, sodium chloride $(\mathrm{NaCl}, 99 \%)$, potassium chloride $(\mathrm{KCl}, 99 \%)$, potassium phosphate dibasic $\left(\mathrm{K}_{2} \mathrm{HPO}_{4}, 98 \%\right)$, HEPES $\left(\mathrm{C}_{8} \mathrm{H}_{18} \mathrm{~N}_{2} \mathrm{O}_{4} \mathrm{~S}, 99.5 \%\right)$, calcium chloride $\left(\mathrm{CaCl}_{2}, 97 \%\right)$, magnesium chloride $\left(\mathrm{MgCl}_{2}, 98 \%\right)$, sodium phosphate dibasic $\left(\mathrm{Na}_{2} \mathrm{HPO}_{4}, 99 \%\right)$, and citric acid $\left(\mathrm{C}_{6} \mathrm{H}_{8} \mathrm{O}_{7}, 99 \%\right)$ were purchased from Sigma-Aldrich (St. Louis, MO). Highpurity deionized (DI) water was obtained with a Millipore water system. Gibco® Dulbecco's modified eagle medium (DMEM, high glucose, GlutaMAX ${ }^{\mathrm{TM}}$ Supplement) and fetal bovine serum (FBS) were purchased from Life Technologies (Grand Island, NY).

\subsection{Fabrication and surface modification of gold Q3D-PNA SERS substrates}

Gold Q3D-PNAs $(50 \mu \mathrm{m} \times 50 \mu \mathrm{m})$ with a square grid of $400 \mathrm{~nm}$ diameter and $100 \mathrm{~nm}$ spacing were fabricated by electron beam lithography (EBL) following the same method reported previously (Sun et al. 2014; Sun et al. 2015). Scanning electron microscope (SEM, FEI Sirion) and tapping mode atomic force microscope (AFM, DI MultiMode with Nanoscope Iva controller) were used to characterize the dimensions of the nanostructures. The 4-MBA self-assemble monolyaer (SAM) was formed on the surface of the Q3D-PNA SERS substrate by soaking an UV ozone-cleaned substrate in a $0.1 \mathrm{mM} 4-\mathrm{MBA}$ in ethanol for $12 \mathrm{~h}$, followed by rinsing with ethanol, deionized (DI) water and blowing dry in a stream of nitrogen.

\subsection{Generation of $\mathrm{pH}$ calibration curves}

The $\mathrm{pH}$ calibration curves were generated from different solutions including, intracellular mimic (IC: $5 \mathrm{mM} \mathrm{NaCl} ; 120 \mathrm{mM} \mathrm{KCl} ; 10 \mathrm{mM} \mathrm{K}{ }_{2} \mathrm{HPO}_{4} ; 25 \mathrm{mM}$ HEPES; 0.15 $\mathrm{mM} \mathrm{CaCl} 2 ; 5 \mathrm{mM} \mathrm{MgCl}_{2} ; \mathrm{pH}$ adjusted with $\mathrm{KOH}$ and $\mathrm{HCl}$ ), cell culture medium (CM: 
DMEM with additional $25 \mathrm{mM}$ HEPES and 10\% fetal bovine serum; pH adjusted with $\mathrm{NaOH}$ and $\mathrm{HCl}$ ), PBS (10 mM Na $2 \mathrm{HPO}_{4} ; 1.8 \mathrm{mM} \mathrm{KH}_{2} \mathrm{PO}_{4} ; 138 \mathrm{mM} \mathrm{NaCl} ; 2.7 \mathrm{mM} \mathrm{KCl} ; \mathrm{pH}$ adjusted with $\mathrm{NaOH}$ and $\mathrm{HCl}$ ), DI water (pH adjusted with $\mathrm{NaOH}$ and $\mathrm{HCl}$ ) and phosphate citrate buffer (PC: mixing aqueous solutions of $\mathrm{Na}_{2} \mathrm{HPO}_{4}(200 \mathrm{mM})$ and citric acid $(100 \mathrm{mM})$ with different volume ratios for desired $\mathrm{pH}$ ).

Raman spectroscopy was carried out on a Renishaw InVia Raman spectroscope connected to a Leica DMLM upright microscope. A $50 \times /$ N.A. $=0.8$ objective was used to focus a $785 \mathrm{~nm}$ laser on a Q3D-PNA, and to collect the $180^{\circ}$ scattered light from the sample surface. The 4-MBA modified SERS substrates were submersed in different solutions in a custom-made container and covered with a glass slide on the top to take SERS spectra in a wet condition. The laser power was set at $1 \mathrm{~mW}$ and the exposure time was $10 \mathrm{~s}$. Spectral resolution of $1.1 \mathrm{~cm}^{-1}$ can be achieved and spectra ranging from 400 to $1800 \mathrm{~cm}^{-1}$ were collected. The $\mathrm{pH}$ calibration curves were generated by plotting the relative intensities of the $v \mathrm{COO}^{-}$mode to the benzene ring $v 8 a$ mode as a function of $\mathrm{pH}$.

\subsection{Cell seeding on the Q3D-PNA SERS substrates}

Prior to cell culture, the 4-MBA modified Q3D-PNA SERS substrates were sterilized by soaking and rinsing with copious amounts of ethanol. Two sterilized SERS substrates each with 4 of $50 \mu \mathrm{m} \times 50 \mu \mathrm{m}$ Q3D-PNA patterns were attached to custom-made Teflon holders and then they were placed in two petri dishes. To them, NIH/3T3 and HepG2 cells (ATCC, Manassas, VA) were plated separately in each at about $4 \times 10^{4}$ cells $/ \mathrm{mL}$ in DMEM with additional $25 \mathrm{mM}$ HEPES and $10 \%$ FBS in a $5 \% \mathrm{CO}_{2}$ incubator at $37{ }^{\circ} \mathrm{C}$ for $24 \mathrm{~h}$.

\subsection{Optical imaging and SERS mapping of $\mathrm{pH}_{\mathrm{e}}$ of living cells}

The optical images of NIH/3T3 and HepG2 after $24 \mathrm{~h}$ incubation on the 4-MBA modified Q3D-PNA SERS substrates were taken using $10 \times /$ N.A. $=0.3$ and $50 \times /$ N.A. $=0.8$ lenses. The Teflon holders with SERS substrates and cultured cells were taken out of the petri 
dishes after $24 \mathrm{~h}$ incubation. A cover glass was carefully put over the top opening of the Teflon holder. The optical and Raman images were taken directly from these samples by impinging the light or laser through the cover glass and focsing on the sample surface.

The bright field and dark field images of cells on the Q3D-PNA patterns were taken with the $50 \times /$ N.A. $=0.8$ lens. The SERS spectra of NIH/3T3 and HepG2 cells were taken using the Renishaw InVia confocal Raman microspectrocope in the mapping mode with $1 \mathrm{~mW}$ laser power, $10 \mathrm{~s}$ exposure time and spectral range from 1300 to $1800 \mathrm{~cm}^{-1}$ using a $50 \times / \mathrm{N}$.A. $=$ 0.8 objective with a pinhole to focus the beam to a $\sim 2 \mu \mathrm{m}$ diameter spot. The mapping area was a square of $50 \mu \mathrm{m} \times 50 \mu \mathrm{m}$ covering the Q3D-PNA pattern and the step size was $2 \mu \mathrm{m}$ in both $\mathrm{x}$ - and $\mathrm{y}$-direction.

\section{Results and discussion}

\subsection{High reproducibility of Q3D-PNA SERS substrates}

The SERS substrate for mapping $\mathrm{pH}_{\mathrm{e}}$ of single live cells is critical because it has to be stable, sensitive, spatially uniform and reproducible. In this work, we used the gold Q3D-PNA SERS substrate, which is composed of physically separated subwavelength gold nanodiscs at the bottom and a gold thin film with nanoholes on the top (Figure 1). The SEM and AFM images of Q3D-PNA SERS substrates used in this work are shown in Figure S1 in the Supporting Information (SI). Q3D-PNAs were designed using finite-difference time-domain (FDTD) electromagnetic simulations and fabricated via EBL, which have demonstrated excellent tunable plasmonic and optical properties as well as strong and reproducible SERS signals (Sun et al. 2014; Xu et al. 2011). Figure 2a shows the SERS spectrum of 4-MBA SAM formed on the Q3D-PNA in PBS at $\mathrm{pH}$ 7.4. The peak assignments are summarized in Table $\mathbf{S} 1$ in the SI. Figure $2 \mathrm{~b}$ shows the contour of 32 SERS spectra of 4-MBA collected from the same chip at 32 different locations. The high reproducibility indicates an exceptional 
uniformity of the substrate, which is crucial for SERS mapping in order to yield a complete and meaningful spectral map.

\section{2 pH response of 4-MBA modified Q3D-PNA SERS substrates in PBS}

To measure $\mathrm{pH}$ response, a 4-MBA modified Q3D-PNA SERS substrate was immersed in PBS with the $\mathrm{pH}$ being adjusted from $\sim 4.0$ to $~ 9.0$. Figure 3a shows the SERS spectra in the window of $1300-1800 \mathrm{~cm}^{-1}$, which is the range with the most prominent spectral changes as a function of $\mathrm{pH}$. All the spectra are normalized at the intense peak at $1586 \mathrm{~cm}^{-1}$, assigned as the aromatic ring breathing mode $(v 8 a)$. The peak at $\sim 1420 \mathrm{~cm}^{-1}$, which belongs to the symmetric $\mathrm{COO}^{-}$stretching mode $\left(\mathrm{COOO}^{-}\right)$, increases with the increasing of $\mathrm{pH}$. A larger increase was observed for the $\mathrm{pH}$ greater than $\sim 6.5$ because of the deprotonation of more carboxyl groups (Figure 3b). The peak also redshifts with the increasing of $\mathrm{pH}$ suggesting that some 4-MBA molecules may still be involved in hydrogen bonding in addition to the possible interaction between $\mathrm{COO}^{-}$groups and the ring hydrogens. It was also noticed that the shoulder

at $\sim 1690 \mathrm{~cm}^{-1}$ due to the symmetric $\mathrm{C}=\mathrm{O}$ stretching mode decreases with the increasing of $\mathrm{pH}$ (Figure 3a). The inverse behaviors of these two peaks were observed in the previous reports (Bishnoi et al. 2006; Kneipp et al. 2007; Pallaoro et al. 2010; Scaffidi et al. 2009; Talley et al. 2004). Because of the sensitive response to solution $\mathrm{pH}$, the intensity of the $v C O O^{-}$peak will be used as the $\mathrm{pH}$ indicator in this work.

\subsection{Interferences from cations and calibrations in different solutions}

However, the $v \mathrm{COO}^{-}$peak of 4-MBA not only responds to the variation of solution $\mathrm{pH}$ due to protonation/deprotonation, but also changes with the presence of cations in solution due to chelation. This effect has been used to detect heavy metal ions using SERS by monitoring the shift and intensity change of the $v C O O^{-}$peak (Lee and Moskovits 2010). In this work, mapping $\mathrm{pH}_{\mathrm{e}}$ of living cells using SERS would be conducted in situ in cell culture media after $24 \mathrm{~h}$ incubation. $\mathrm{Na}^{+}$and $\mathrm{K}^{+}$are the major cations in cell culture media and they have a reverse 
concentration gradient across the cell membrane to maintain the resting potential (Williams 1970). A small amount of divalent cations $\mathrm{Ca}^{2+}$ and $\mathrm{Mg}^{2+}$ are also present in most of the cell culture media. Cells maintain relative high concentrations of $\mathrm{Mg}^{2+}$ but pump $\mathrm{Ca}^{2+}$ out (JahnenDechent and Ketteler 2012). Thus, we studied the potential interferences of these four types of cations $\left(\mathrm{Na}^{+}, \mathrm{K}^{+}, \mathrm{Ca}^{2+}\right.$ and $\left.\mathrm{Mg}^{2+}\right)$ on the SERS peak of $v C O O^{-}$by adding them one at a time to the pure deionized (DI) water while keeping a constant $\mathrm{pH}$ of 7.0 in order to evaluate the cation effect. Figure 4a shows the SERS spectra in the window of $1350-1500 \mathrm{~cm}^{-1}$ of these solutions and DI water. Adding $10 \mathrm{mM} \mathrm{Na}^{+}$or $\mathrm{K}^{+}$in DI water does not induce any spectral change of the $v C O O^{-}$peak. The presence of $10 \mathrm{mM} \mathrm{Ca}^{2+}$ causes the $v C O O^{-}$peak to redshift about $6 \mathrm{~cm}^{-1}$ and to slightly decrease peak intensity. By adding $10 \mathrm{mM} \mathrm{Mg}{ }^{2+}$, the peak also shows a shift of about $8 \mathrm{~cm}^{-1}$ to high wavenumber and a relatively large intensity increase. The SERS spectral changes imply the variations of polarizability of $\mathrm{COO}^{-}$induced by the chelation of different cations. The divalent cations exhibit more influences on the ${ } C O O^{-}$peak comparing with the monovalent cations because of their higher binding affinities to the carboxylate group (Le Calvez et al. 2001). Since the relative intensity of the $v C O O^{-}$peak to the benzene ring $v 8 a$ peak is used to detect $\mathrm{pH}$, the intensity change of the $v C O O^{-}$peak with the presence of cations, especially divalent cations, does affect the detection accuracy of this method. In addition, the detection could also be affected by the ionic strength of a solution due to the formation of an electrical double layer that affects the diffusion of protons and other cations. Therefore, it is necessary to measure the $\mathrm{pH}$ calibration curves under the real detection conditions.

We investigated the $\mathrm{pH}$ response of the $\mathrm{vCOO}^{-}$peak in different solutions including, intracellular mimic (IC), cell culture medium (CM), PBS, DI water and phosphate citrate buffer (PC). Figure $4 \mathrm{~b}$ shows the relative intensities of the $v \mathrm{COO}^{-}$mode to the benzene ring $v 8 a$ mode as a function of $\mathrm{pH}$ in aforementioned solutions, and the error bars correspond to the 
standard deviation of five replicates. Notably, the calibration curves of different solutions are not identical. At the same $\mathrm{pH}$, the relative intensities of the peaks of $v C O O^{-}$over $v 8 a$ from the intracellular mimic and cell culture medium are much higher than those from the other solutions because of the presence of divalent ions $\left(5 \mathrm{mM} \mathrm{Mg}^{2+}\right.$ and $\left.0.15 \mathrm{mM} \mathrm{Ca}^{2+}\right)$ in intracellular mimic and the complexity of the cell culture medium. Clearly, errors would be introduced in the measurements of $\mathrm{pH}_{\mathrm{i}}$ or $\mathrm{pH}_{\mathrm{e}}$ if they are simply based on the calibration curve built from a buffer solution but in fact that 4-MBA modified SERS substrates are surrounded by complex biological media. Since we would culture the cells on the SERS substrates and map the $\mathrm{pH}_{\mathrm{e}}$ in situ in the cell culture medium after incubation, we generated the $\mathrm{pH}$ calibration curve for the cell culture medium. Remarkably, the calibration curve of the cell culture medium shows a steeper slope between $\mathrm{pH} 7.0$ and 7.6, offering a resolution of about $0.1 \mathrm{pH}$ units across this range, which is also the ideal range of $\mathrm{pH}_{\mathrm{e}}, \mathrm{A}$ similar $\mathrm{pH}$ sensitivity was reported with 4-MBA modified gold-nanoshells (Bishnoi et al. 2006). This $\mathrm{pH}$ sensitivity is essential in order to distinguish the $\mathrm{pH}$ differences of the microenvironment outside the living cell membranes.

\subsection{Mapping extracellular $\mathrm{pH}$ of living normal and cancer cells in cell culture media}

To demonstrate the capability of 4-MBA modified Q3D-PNA SERS substrates in the detection and mapping of the $\mathrm{pH}_{\mathrm{e}}$ distribution of single living cells, $\mathrm{NIH} / 3 \mathrm{~T} 3$ and HepG2 cells were cultured directly on the SERS substrates that were placed in each of the two petri dishes in the cell culture medium for $24 \mathrm{~h}$. A control set was run in parallel by just adding the cell culture medium. After incubation, the optical images and the $\mathrm{pH}_{\mathrm{e}} \mathrm{SERS}$ mapping of the cells were taken in situ using the Renishaw Raman microspectroscopy system. The first row of Figure 5a shows the 10X optical images of NIH/3T3, HepG2 and the control set on the SERS substrates in bright field. All the cells were well grown and attached to the SERS substrate. The dark squares in the middle are the Q3D-PNAs. The images in the second and third rows 
are the 50X optical images in bright field and dark field, respectively. The shapes of cell bodies are blurry in the bright field images due to the use of the reflective optical microscope mode, while they are clearer in the dark field images confirming the well attached cells on the Q3D-PNAs.

The $\mathrm{pH}_{\mathrm{e}}$ distributions of living cells were mapped out by generating the 2D SERS images of local $\mathrm{pH}$ values, which were determined from the calibration curve of the cell culture medium in Figure 4b. The forth row in Figure 5a shows the SERS pH images of the Q3D-PNA area $(50 \mu \mathrm{m} \times 50 \mu \mathrm{m})$ with the NIH/3T3 and HepG2 samples, corresponding to the optical images shown in the second and the third rows. The control set of the cell culture medium was only measured in the center area of the Q3D-PNA, and a uniform $\mathrm{pH}$ distribution around 7.5-7.6 was observed. Clearly, the areas of no cells in the SERS pH images of the $\mathrm{NIH} / 3 \mathrm{~T} 3$ and HepG2 samples display the similar $\mathrm{pH}$ range (green color) as that in the control set. The areas where cells attached show lower $\mathrm{pH}$ than the area of the cell culture medium only. The $\mathrm{pH}_{\mathrm{e}}$ distributions and microdomains at the plasma membrane of both NIH/3T3 and HepG2 cells are shown by color contrast in the $\mathrm{pH}_{\mathrm{e}}$ SERS images. The different $\mathrm{pH}_{\mathrm{e}}$ values of the cell membranes are believed to be related to the $\mathrm{Na}^{+} / \mathrm{H}^{+}$exchangers such as NHE1 distributed in cell membranes that extrude the excess protons outside of the cell (Cardone et al. 2005). Increased expression and activity of these $\mathrm{Na}^{+} / \mathrm{H}^{+}$exchangers are observed in tumor cells. And the more acidic microenvironment outside the tumor cells is also due to their more glycolytic phenotype. Figure 5 b shows histograms of the $\mathrm{pH}_{\mathrm{e}}$ of NIH/3T3 and HepG2. The averaged $\mathrm{pH}_{\mathrm{e}}$ of the tumor cells HepG2 $(\mathrm{pH} 7.29 \pm 0.06)$ is more acidic than that of the normal NIH/3T3 cells (pH $7.43 \pm 0.10)$ shown in Figure 5c. This mapping technique can be used to study the cells adhesion and migration regulated by $\mathrm{pH}_{\mathrm{e}}$.

\section{Conclusion}


In summary, based on the excellent uniformity and reproducibility of Q3D-PNA SERS substrates and the $\mathrm{pH}$ calibration curve achieved in the cell culture medium, the $\mathrm{pH}_{\mathrm{e}}$ distributions of living cells were mapped out by using 4-MBA modified SERS substrates. This technique can be used for the differentiation between normal and tumor cells. Moreover, it will benefit the study of metabolisms and functions of living cells as well as transmembrane drug delivery ruled by the extracellular acidity.

\section{Acknowledgements}

This work was supported by National Science Foundation (NSF, CBET 1158609 (QY) and CBET 1264470 (SJ)). The Q3D-PNA arrays on a silicon wafer were fabricated using EBL by Dr. Richard Bojko at the Washington Nanofabrication Facility (WNF) and the Raman experiments were performed at the Nanotech User Facility (NTUF). WNF/NTUF is the UW site of the National Nanotechnology Infrastructure Network (NNIN) supported by the NSF.

\section{References}

Bishnoi, S.W., Rozell, C.J., Levin, C.S., Gheith, M.K., Johnson, B.R., Johnson, D.H., Halas, N.J., 2006. Nano Lett. 6(8), 1687-1692.

Bizzarri, R., Arcangeli, C., Arosio, D., Ricci, F., Faraci, P., Cardarelli, F., Beltram, F., 2006. Biophys. J. 90(9), 3300-3314.

Cardone, R.A., Casavola, V., Reshkin, S.J., 2005. Nat. Rev. Cancer 5(10), 786-795.

García-Martín, M.-L., Hérigault, G., Rémy, C., Farion, R., Ballesteros, P., Coles, J.A., Cerdán, S., Ziegler, A., 2001. Cancer Res. 61(17), 6524-6531.

Gerweck, L.E., Seetharaman, K., 1996. Cancer Res. 56(6), 1194-1198. 
Gillies, R.J., Raghunand, N., Karczmar, G.S., Bhujwalla, Z.M., 2002. J. of Magnetic Resonance Imaging 16(4), 430-450.

Jahnen-Dechent, W., Ketteler, M., 2012. Clinical Kidney J. 5(Suppl. 1), i3-i14.

Ke, G., Zhu, Z., Wang, W., Zou, Y., Guan, Z., Jia, S., Zhang, H., Wu, X., Yang, C.J., 2014. ACS Appl. Mater. Inter. 6(17), 15329-15334.

Kneipp, J., Kneipp, H., Wittig, B., Kneipp, K., 2007. Nano Lett. 7(9), 2819-2823.

Lardner, A., 2001. J. of Leukoc. Biology 69(4), 522-530.

Le Calvez, E., Blaudez, D., Buffeteau, T., Desbat, B., 2001. Langmuir 17(3), 670-674.

Lee, S.J., Moskovits, M., 2010. Nano Lett. 11(1), 145-150.

Pallaoro, A., Braun, G.B., Reich, N., Moskovits, M., 2010. Small 6(5), 618-622.

Scaffidi, J.P., Gregas, M.K., Seewaldt, V., Vo-Dinh, T., 2009. Anal. Bioanal. Chem. 393(4), 1135-1141.

Schlucker, S., 2014. Angew. Chem. Int. Edit. 53(19), 4756-4795.

Song, C.W., Griffin, R., Park, H.J., 2006. Influence of tumor pH on therapeutic response, in: Teicher, B.A., Cancer drug resistance. Springer, New York, pp. 21-42.

Sun, F., Bai, T., Zhang, L., Ella-Menye, J.R., Liu, S.J., Nowinski, A.K., Jiang, S.Y., Yu, Q.M., 2014. Anal. Chem. 86(5), 2387-2394.

Sun, F., Ella-Menye, J.R., Galvan, D.D., Bai, T., Hung, H.C., Chou, Y.N., Zhang, P., Jiang, S., Yu, Q., 2015. ACS Nano 9(3), 2668-2676.

Talley, C.E., Jusinski, L., Hollars, C.W., Lane, S.M., Huser, T., 2004. Anal. Chem. 76(23), 7064-7068.

Webb, B.A., Chimenti, M., Jacobson, M.P., Barber, D.L., 2011. Nat. Rev. Cancer 11(9), 671677.

Williams, R., 1970. Q. Rev. Chem. Soc. 24(3), 331-365.

Xu, J.J., Zhang, L., Gong, H., Homola, J., Yu, Q.M., 2011. Small 7(3), 371-376. 


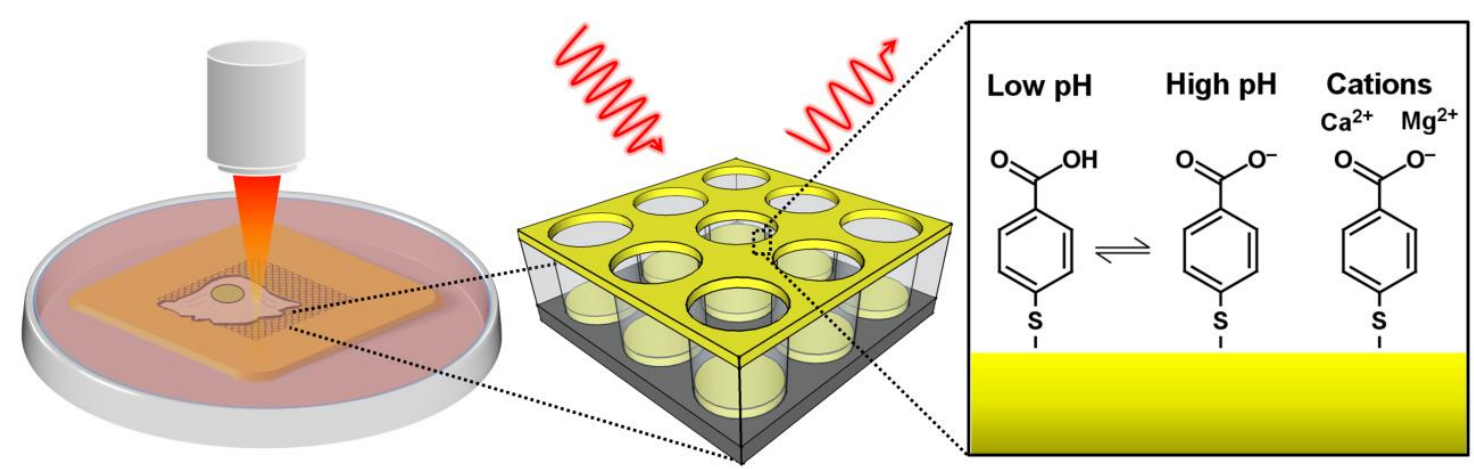

Figure 1. Schematic illustration of mapping $\mathrm{pH}_{\mathrm{e}}$ of a single living cell cultured on a 4-MBA modified Q3D-PNA SERS substrate in the culture media. 

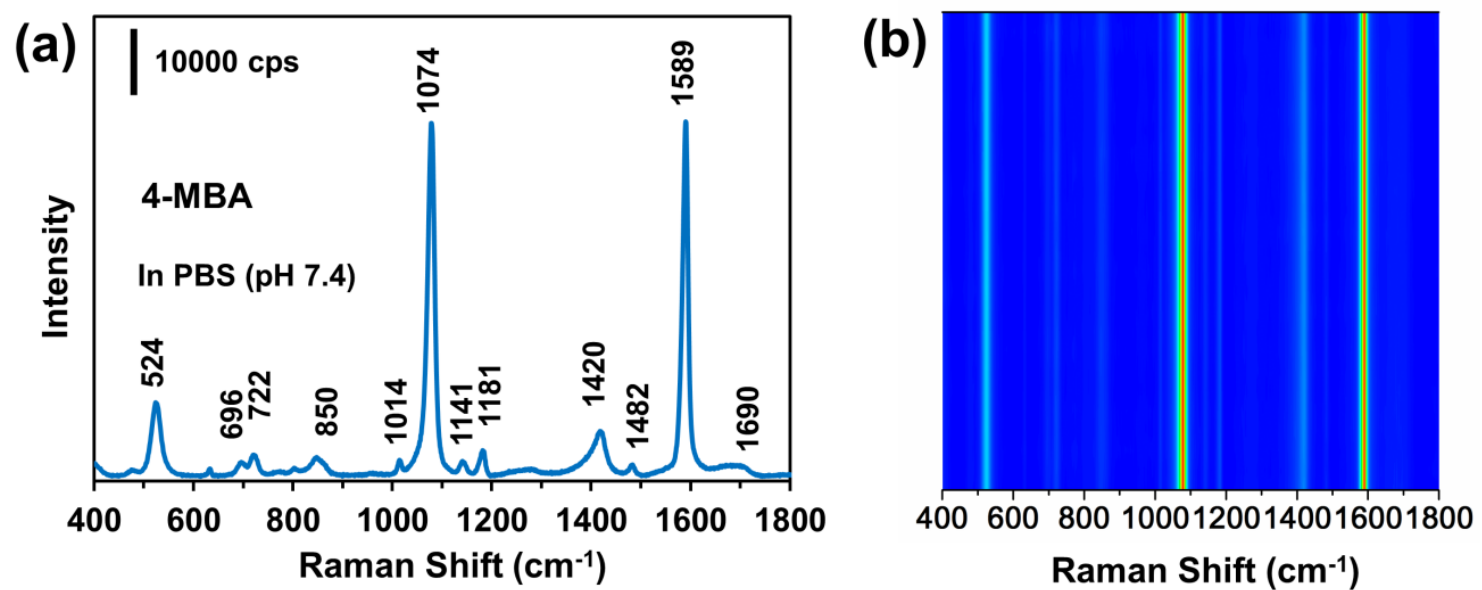

Figure 2. (a) SERS spectrum of 4-MBA in PBS (pH 7.4). The $\lambda_{\mathrm{ex}}=785 \mathrm{~nm}, \mathrm{P}_{\text {laser }}=1 \mathrm{~mW}$, and $t=10$ s. (b) SERS contour of 32 spectra of 4-MBA collected from different spots on one Q3D-PNA SERS substrate. 

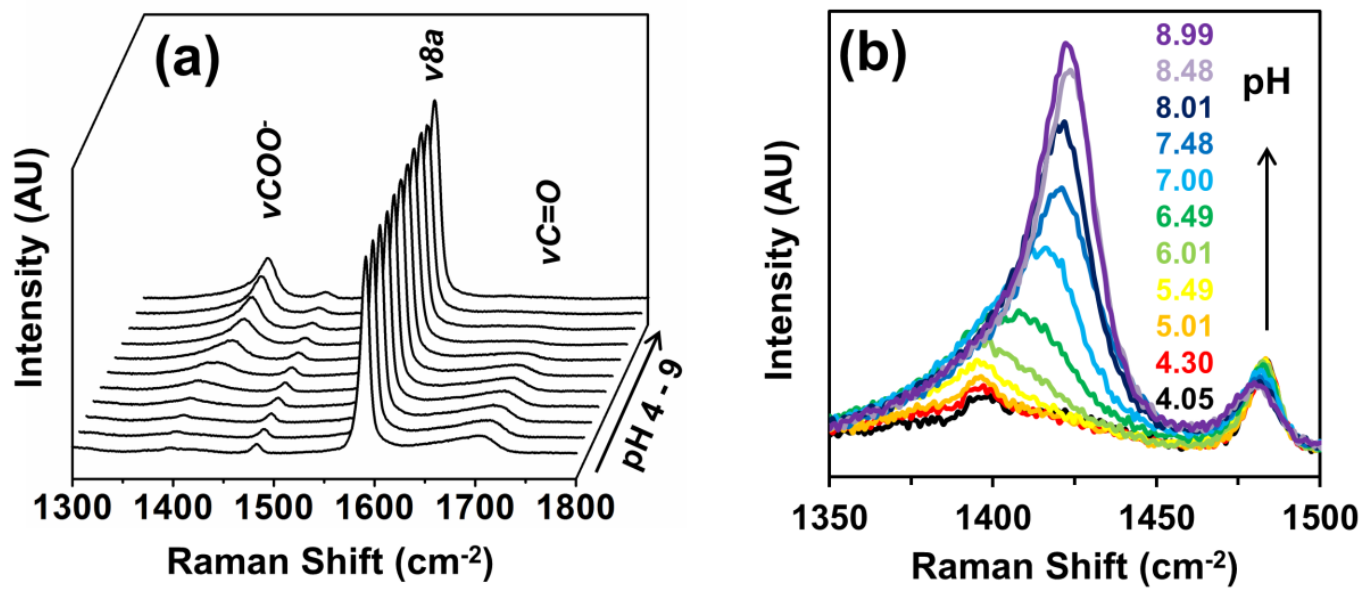

Figure 3. (a) SERS spectra of 4-MBA modified Q3D-PNA substrates in PBS with $\mathrm{pH}$ from $\sim 4.0$ to $\sim 9.0$. (b) A close-look of the intensity of the $v C O O^{-}$mode at $\sim 1420 \mathrm{~cm}^{-1}$ varies with $\mathrm{pH}$ due to its degree of protonation/deprotonation. 

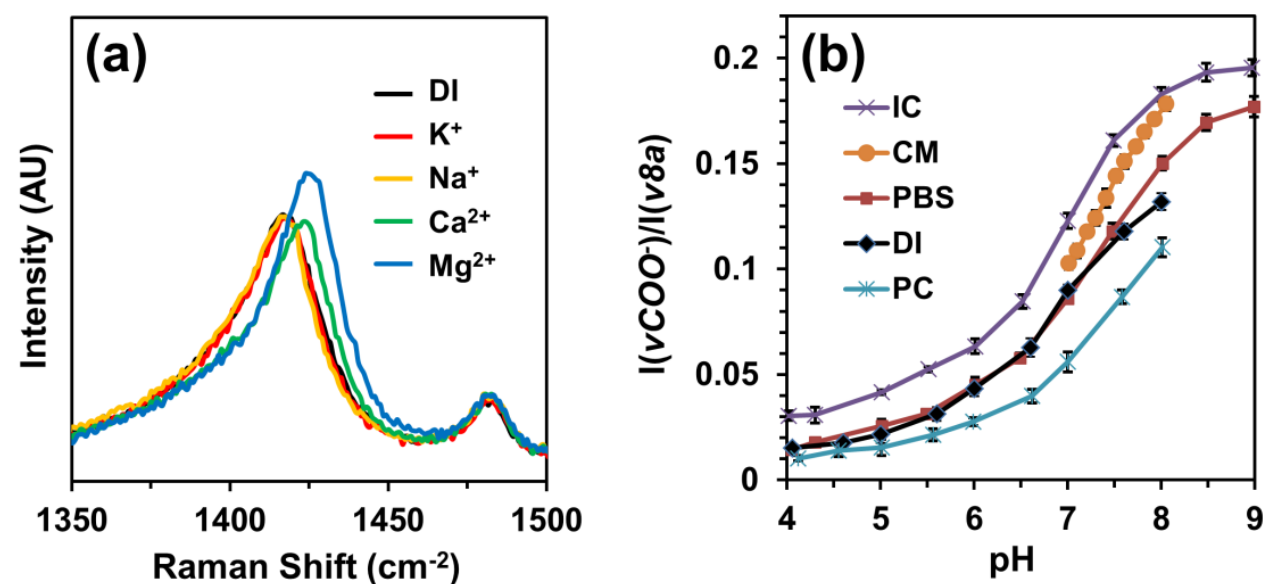

Figure 4. (a) The peak of the $v C O O^{-}$mode at $\sim 1420 \mathrm{~cm}^{-1}$ varies with the presence of $10 \mathrm{mM}$ different cations in DI water at $\mathrm{pH}$ 7.0. (b) The $\mathrm{pH}$ calibration curves for different detection solutions made by plotting the relative intensities of the $v C O O^{-}$to the benzene ring $v 8 a$ mode as a function of $\mathrm{pH}$. 
(a) NIH/3T3
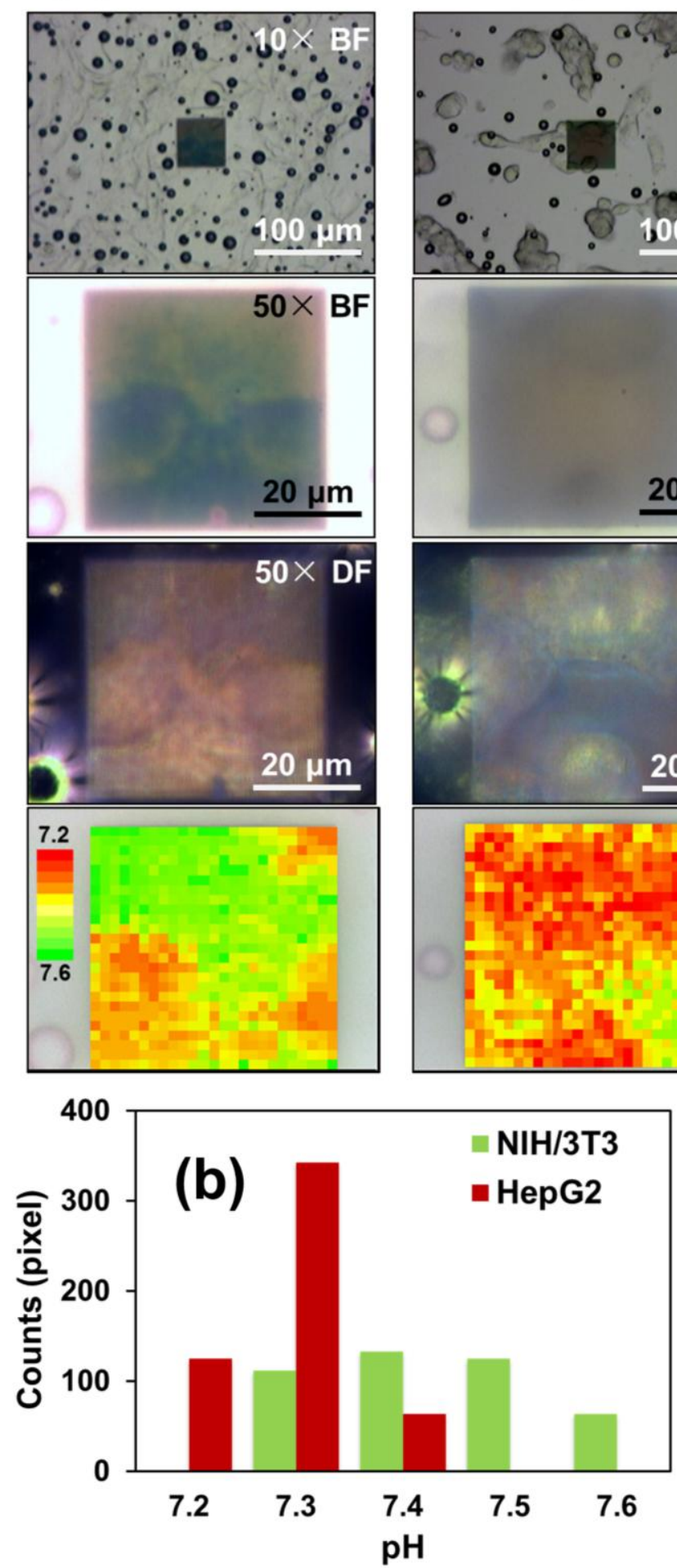

HepG2
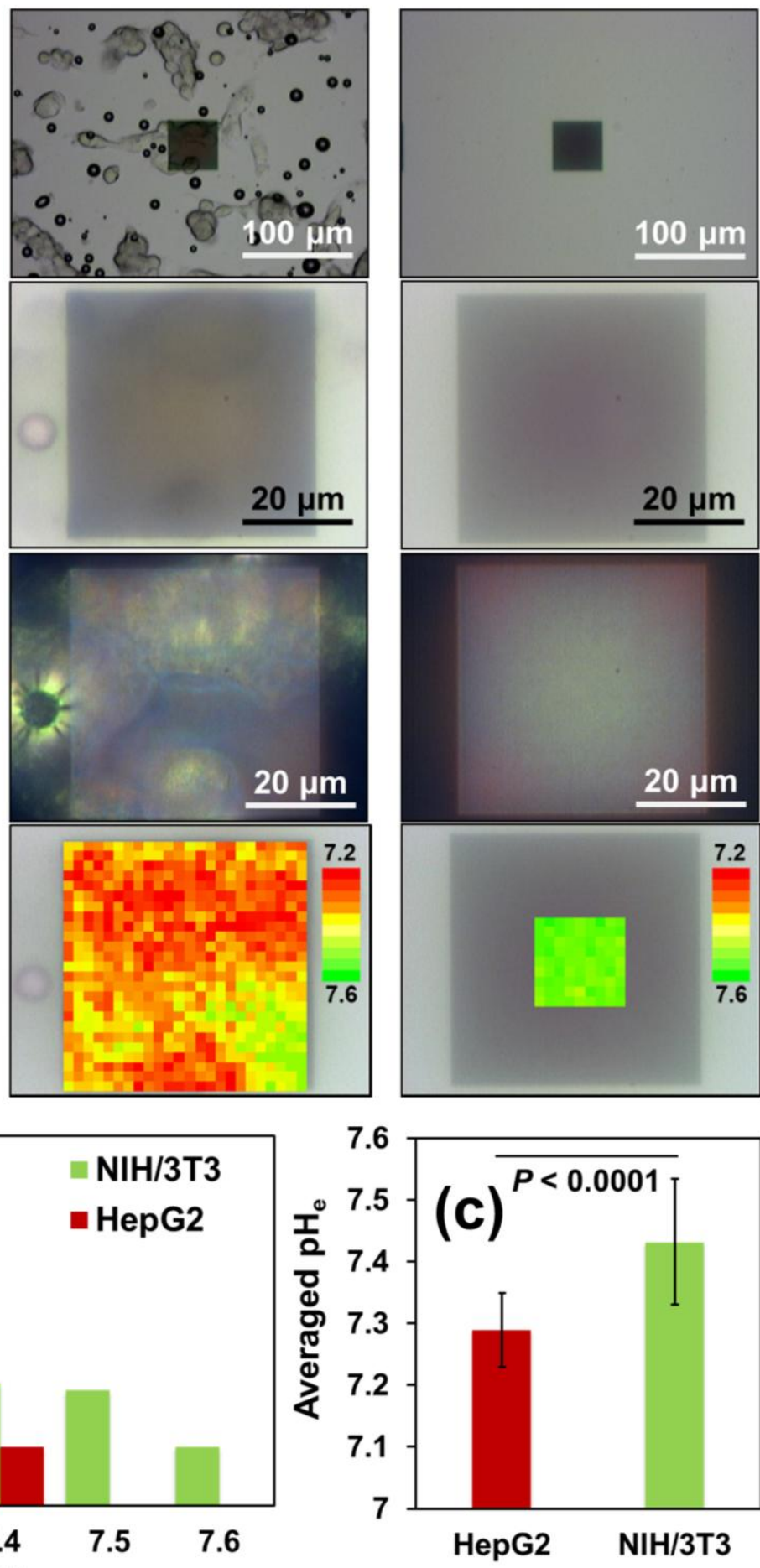

Figure 5. (a) Optical images and $\mathrm{pH}_{\mathrm{e}} \mathrm{SERS}$ mapping of $\mathrm{NIH} / 3 \mathrm{~T} 3$ and $\mathrm{HepG} 2$ cells cultured on the 4-MBA modified Q3D-PNA SERS substrates in the CM. The control was the 4-MBA modified Q3D-PNA in the CM only. (b) Histogram of the $\mathrm{pH}_{\mathrm{e}}$ of NIH/3T3 and HepG2 cells. (c) Averaged $\mathrm{pH}_{\mathrm{e}}$ of NIH/3T3 and HepG2 cells (collected from 5 cells, independent t-test, $P<$ 0.0001). 
Functionalized Plasmonic Nanostructure Arrays for Direct and Accurate Mapping Extracellular pH of Livng Cells in Complex Media Using SERS

F. Sun, P. Zhang, T. Bai, D.D. Galvan, Dr. H. Hung, N. Zhou, Prof. S. Jiang and Prof. Q. Yu*

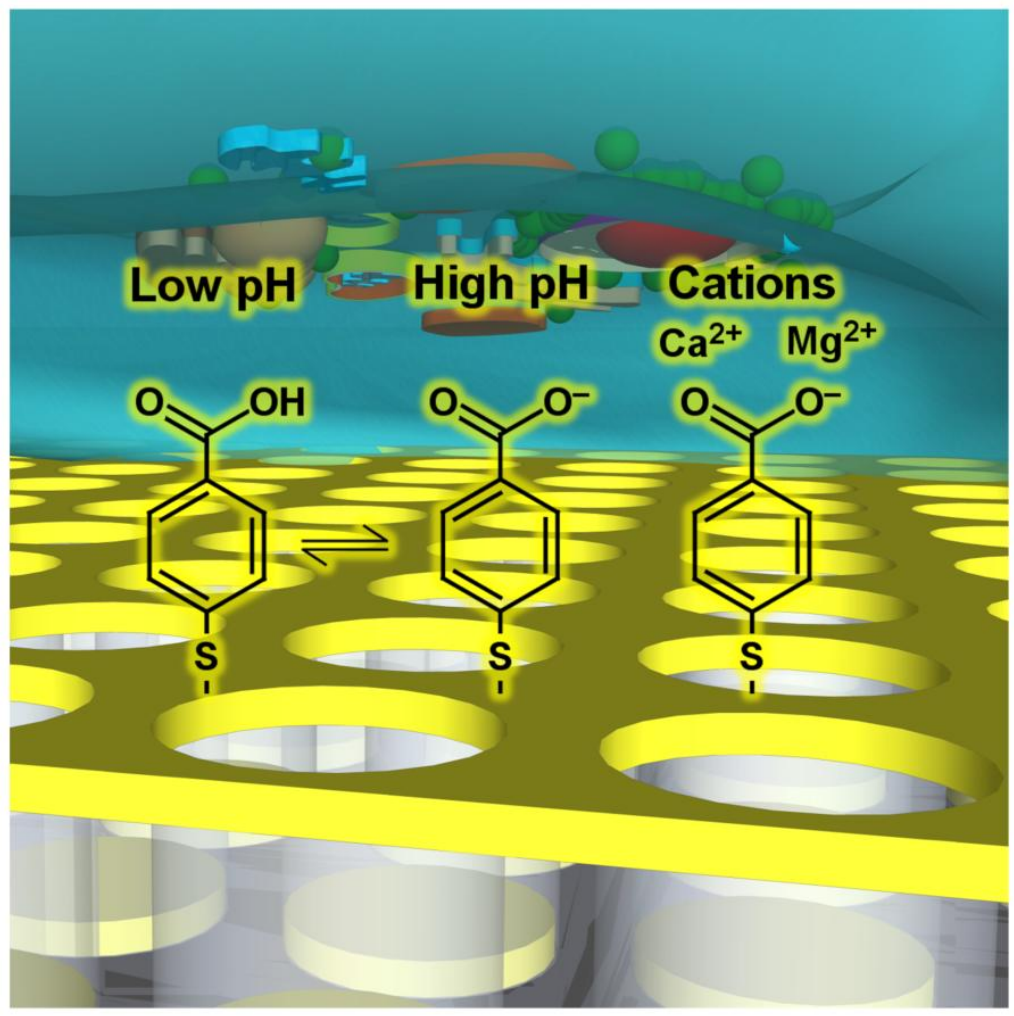

Mapping $\mathrm{pH}_{\mathrm{e}}$

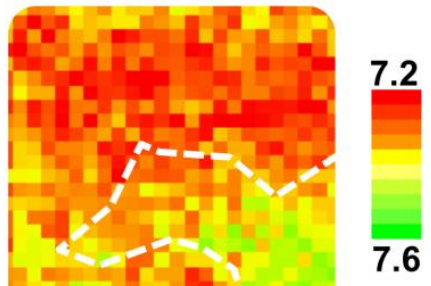

Tumor cell

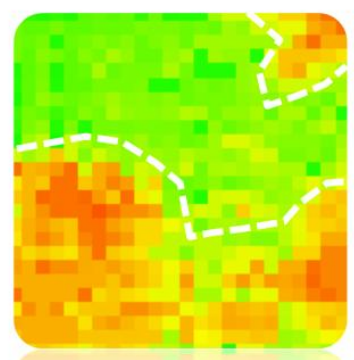

7.2

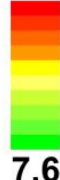

Normal cell 